\title{
CORPORATE REPUTATION AND CUSTOMER SATISFACTION IN THE TELECOMMUNICATION INDUSTRY IN NIGERIA
}

\author{
Ananaba Ugwunwanyi ${ }^{1}$, Samuel Ngozichikanma Nwosu ${ }^{2}$, \\ Udoka Stephen Otika $^{3}$ and Oby Blessing Osuagwu ${ }^{4}$
}

${ }^{1}$ Department of Industrial Relations and Personnel Management, Michael Okpara University of Agriculture, Umudike. Email: ananabaug09@yahoo.com

${ }^{2}$ Department of Accounting, Evangel University, Akaeze, Ebonyi State. Email: samca880@gmail.com

${ }^{3}$ Department of Marketing, Evangel University, Akaeze, Ebonyi State Email: ud.otika@evangeluniversity.edu.ng

\author{
${ }^{4}$ Department of Business Administration, Hezekiah University, Umudi, Imo State, Nigeria \\ Email: rhina.201@gmail.com
}

Cite this article:

Ananaba U., Nwosu S.N., Otika U.S., Osuagwu O.B. (2021), Corporate Reputation and Customer Satisfaction in the Telecommunication Industry in Nigeria. African Journal of Social Sciences and Humanities Research 4(4), 107-125. DOI: 10.52589/AJSSHRAQJ7E4OQ.

\section{Manuscript History}

Received: 10 Oct 2021

Accepted: 1 Nov 2021

Published: 14 Nov 2021

Copyright $\odot 2020$ The Author(s). This is an Open Access article distributed under the terms of Creative Commons AttributionNonCommercial-NoDerivatives 4.0 International (CC BY-NC-ND 4.0 ), which permits anyone to share, use, reproduce and redistribute in any medium, provided the original author and source are credited.
ABSTRACT: Despite the widespread belief that corporate reputation is a valuable intangible asset that helps firms to compete favourably in the telecommunication industry, the scientific evidence is deficient on how corporate reputation influence customer satisfaction in the study area. The study focused on the relationship between corporate reputation and customer satisfaction. The survey research design method was employed in the study. The research instrument was a validated structured questionnaire. The reliability of the questionnaire was estimated by assessing the internal consistency of the items representing each construct. Cronbach's alpha was used to establish the reliability of the constructs. The correlation and multiple regression analyses were used in the study. The sample size of 135 respondents was administered with the questionnaire. The finding of the analyses revealed that trustworthiness $(B=0.251, P<.001)$; corporate social responsibility $(B=0.283, P<.001)$; credibility $(B=0.198, P<.001)$ and reliability $(B=0.219, P<.001)$ were respectively significant and exhibited significant positive effects on customer satisfaction. The major conclusion that emerged from the findings is that corporate reputation is a multifaceted construct whose dimensions have significant positive relationships with marketing performance outcome of customer satisfaction in the mobile telecommunications services industry. In the competitive context, managers should apply the dimensions of corporate reputation that is appropriate for their target segment and develop their customer satisfaction strategy.

KEYWORDS: Corporate Reputation, Trustworthiness, Corporate Social Responsibility, Credibility, Reliability, Customer Satisfaction 


\section{INTRODUCTION}

Corporate reputation has been accentuated to series of scholarly studies in management and allied social science research. Many scholars and professionals posit that the reputation of an organization remains its critical point of appeal to different stakeholders, its personality and social esteem, its most important asset, the content of its character, as well as its current realities as a consequence generated from its past actions. It is generally held by scholars and professionals that corporate reputation constitutes the nucleus intangible properties that define how an organization will fare in a competitive market (Adoro \& Eguruhin, 2000), the quality of support it gets from its stakeholders during a crisis (Domen, 2003), Its foray into new market or industry (Allen-Bach, 2000) and most importantly, the quality of talents it attracts and retains over a long period. Corporate reputation is directly connected to the corporate identity of an organization. It is viewed as ethos, aspirations, values, and goals that drive a sense of commonness and alignment among the organization's stakeholders. The critical role of corporate reputation in building and sustaining the optimal performance of an organization across all fronts cannot be undermined. Performing companies place a vital premium on corporate reputation, hence the huge investments that are lavished on initiatives that are targeted at developing and managing competitive corporate reputation (Adoro \& Eguruhin, 2000), According to (Ozerali, 2004), Corporate reputation affects corporate behaviour, the strategic direction of an organization and the observable corporate traits in which an organization undertake the process of decision-making and planning manner especially concerning critical issues that are vital to its survival, growth, and profitability. Research evidence shows that corporate reputation has significant implications on a variety of organizational and business issues including costs (Deephouse, 2000) and pricing policies (Rindova et al., 2005).

Customer satisfaction, on the other hand, is the primary mental state of the customer which comprises two things: (1) Expectation before purchase, and (2) Perception of the performance after purchase (Oliver 2000; \& Satendra et al, 2011). Customer satisfaction can be defined using the transaction-specific perspective or cumulative perspective. The transaction perspective indicates that customer satisfaction is the evaluation based on the recent purchase experiences (Boulding et al, 2000). Compared with the transaction-specific perspective, the cumulative perspective stresses overall evaluation, indicating that evaluation of customer satisfaction should be based on all the purchase experiences of the customer disregarding any specific purchase experience (Guo et al, 2009). Parasuraman et al, (1988) argued that the cumulative perspective is more capable of evaluating the service performance of firms more effectively in predicting consumers' post-purchase behaviours (Wang et al, 2004). Furthermore, customer satisfaction is a personal feeling of either pleasure or disappointment resulting from the evaluation of services provided by an organization to an individual in relation to expectations. Roberts (2009) defined customer satisfaction as "the degree to which a business's product or service performance matches up to the expectation of the customer. Customer satisfaction is influenced by expectations, perceived service and perceived quality (Turell and Sorento, 2006). Service providers frequently place a higher priority on customer satisfaction because it has been seen as a prerequisite to customer retention. Among the studies of customer satisfaction in the telecommunication and information technology industry, Lin and $\mathrm{Wu}$ (2011) revealed that customer satisfaction of mobile commerce is consumers' total response to the purchase experiences in a mobile commerce environment. Therefore, in this 
study, customer satisfaction is defined as the total consumption perception of consumers when using mobile value-added services.

The Nigerian telecommunication industry has developed to be very competitive, as different telecommunication companies jostle for the attention of subscribers. One of the key challenges confronting these telecommunication companies is how they manage their service quality, which holds a great deal to customer satisfaction. Service quality and customer satisfaction are very essential in maintaining customer loyalty. Having satisfied customers does not only hold the potential of increasing an organization's customer base but also increases the use of a more volatile customer mix and increase the firm's reputation (Alabar, 2012). According to Zeithaml (2000), Manusamy, Chellia, and Mun (2010), delivering high-quality services is closely linked to profits, cost savings and market share. Since survival and growth of a firm's outcome is driven by customer loyalty, which in turn is driven by customer satisfaction and value (Nimako, 2012), delivering quality service and customer satisfaction have been important goals and most perhaps, the pursuit for the expanding mobile telecom networks as well as regulators of the industry.

\section{Statement of the Problems}

Although reputation is an intangible concept, research universally shows a good reputation demonstrably increases corporate worth and provides sustained competitive advantage. A business can achieve its objectives more easily if it has a good reputation among its stakeholders, especially key stakeholders such as its largest customers, opinion leaders in the business community, suppliers, and current and potential employees. (Ozerali, 2004) argue that corporate reputation enables an organization to attract superior talents that deliver on critical corporate capabilities such as innovation, effective internal processes, and innovation. A good reputation is seen as including higher customer retention rates and associated increased sales and product selling prices (Shapiro, 1983), and reduced operating costs (Podony, 1993). Corporate reputation can become merely a mirage when if it is motivated by the pursuit of firms' self-interest. Therefore, the relationship between corporate reputation proxied by (trustworthiness, corporate social responsibility, credibility, reliability) and customer satisfaction is an empirical question. However, the few studies examining this relationship have produced mixed and inconsistent results. Despite widespread belief in this 'reputational advantage', the scientific evidence is deficient on how corporate reputation relates to customer satisfaction in the telecom industry in the study area. Hence, this study is undertaken to fill this identified gap.

\section{Objective of the Study}

The main objective of the study is to examine the significant relationship between corporate reputation and customer satisfaction. Specifically, the study seeks to;

1. Investigate the significant relationship between trustworthiness and customer satisfaction in the Nigerian telecom industry.

2. Examine the significant relationship between corporate social responsibility and customer satisfaction in the Nigerian telecom industry.

3. Ascertain the significant relationship between credibility and customer satisfaction in the Nigerian telecom industry. 
4. Examine the significant relationship between reliability and customer satisfaction in the Nigerian telecom industry.

\section{REVIEW OF RELATED LITERATURE}

\section{Conceptual Framework}

\section{Concept of Corporate Reputation}

With different views on what corporate reputation really is, there has not been consensus agreement on the definition of the concept. One reason for this confusion is that various disciplines define the concept from their own perspectives (Chun 2005). In addition, corporate reputation has a multi-dimensional structure which creates confusion in describing these dimensions, although image and identity are two generally accepted key elements of the concept. However, corporate reputation is commonly considered as an intangible asset shaped by the perceptions of all internal and external stakeholders about the corporation which can affect corporate value. Luis, Jesus, and Belen, (2020) defined corporate reputation as a collective representation of a firm's past actions and results which portray the ability of the firm to deliver valuable outcomes to multiple stakeholders. According to The Oxford Handbook of Corporate Reputation (2012), the concept of corporate reputation first appeared in 1983, and there has been major exponential growth in the scientific literature in the context of reputation.

Reputation is an assessment made by an individual or entity affected by the firm action; reputation is equally referred to as a perception or judgment made by the stakeholders or public or groups that is affecting or affected by the pursuit of the company's objectives (Heinberg, Ozkaya, \& Taube, 2018). Corporate reputations are very important because they enhance economic transactions by providing incentives for the company or firm to behave in acceptable manners. It is designed to deliver sustainable value to society at large, as well as to shareholders" (Shamma 2012). Corporate reputation has been discussed and analyzed in different disciplines. Most studies consider corporate reputation as a strategic asset, claiming that it leads to sustainable profitability, growth and competitive advantage. Such studies have, therefore, mostly focused on the effects of corporate reputation on financial performance (Rose and Thomsen 2004; Krueger, et al. 2010).

However, the most important reason for increased interest in corporate reputation is that it is seen as a strategic asset, with many studies claiming that it leads to sustainable profitability, growth and competitive advantage (Shamma 2012; Adeosun and Ganiyu 2013;). Even though reputation may not be identified as an asset on balance sheets, it affects investor confidence, staff recruitment, supplier attitudes and a myriad of other stakeholders in its capacity as relationship capital (Adeosun and Ganiyu 2013).

Researchers in the past had characterized reputations as the public's overall evaluation of a firm, or a perceptual symbol of a firm's activities and prospects; as well as an attitudinal construct that consists of cognitive (knowledge-based) and affective (emotional-based) components. Luis, Jesus, and Belen, (2020) stated that a positive or favourable reputation indicates that the firm/company has behaved perfectly well over time, leading to higher expectations from the consumers, stakeholders, and public in general. Corporate reputations have attracted attention from an academic perspective due to the thought that it operates in the 
markets for employees (Auger, Devinney, Dowling, Ecker, \& Lin, 2013; Grahame, 2016), customers (Gatti, Caruana, \& Snehota, 2012), and investors (Grahame, 2016). Therefore, a good reputation in the markets is believed to help the firm to attain and retain its so-called stakeholders.

\section{Customer Satisfaction}

Customer satisfaction remains a key discourse among service marketing literature. A customer's desire to remain loyal and purchase or use the services of an organisation in future is dependent on how satisfied the customer is (Shanka, 2012). Thus, a company's continued survival, existence and future growth are largely dependent on the value it places on customer satisfaction (Kim, Park and Jeong, 2012). In today's competitive and dynamic market, the term customer satisfaction (CS) has received much attention and interest among scholars and practitioners. This perhaps can be traced to its importance as a key element of business strategy, and goal for all business activities (Anderson et al, 1994). Jani and Heesup (2011) define satisfaction as an emotional state resulting from a customer's interactions with a service provider over time. Parker and Mathew (2001) identified two basic definitional approaches to the study of CS. The first approach defines CS as an outcome while the second approach views it as a process. It is however important to note that these two approaches are not mutually exclusive but complementary. The process approach of CS is defined as an evaluation between what was received and what was expected (Johnson, 2001; Gustafsson, Johnson \& Roos, 2005), emphasizing the perceptual, evaluative and psychological processes that contribute to customer satisfaction (Vavra, 1997). The process definitions of satisfaction, however, concentrate on the antecedents of satisfaction rather than satisfaction itself (Parker and Mathews, 2001). The outcome approach of the CS is defined as the end-state satisfaction resulting from the experience of consumption. This is a post-consumption state and can be an outcome that occurs without comparing expectations (Oliver, 1996).

Parker and Mathews (2001) further expressed that attention has been focused on the nature of satisfaction of the outcome approach which includes: emotion, fulfilment and state. Gerpott, Rams and Schindler (2001) defined CS as an "experience-based assessment made by the customer of how far his own expectations about the individual characteristics or the overall functionality of the services obtained from the provider have been fulfilled". In this instance, satisfaction is higher or lower with respect to the extent to which what was actually provided exceeds or falls short of what was expected. Rust and Oliver (1994) and Taylor and Baker (1994) identified several factors that precede customer satisfaction and suggested that these factors strongly influence the extent of customer satisfaction. Some of these antecedents include a clear understanding of customer needs and expectations (basic needs, excitement needs and expected needs) and perceived value. However, in the telecom industry, previous research studies have suggested four factors, which are key drivers of the customer value of cellular services, which some are embedded in the above, while some are alien to them. These include network quality, price, customer care, and personal benefits (Bolton, 1998; Gerpott, 1998). 


\section{Corporate Reputation and Consumer Satisfaction}

Corporate is the general perceptions of stakeholders regarding any corporation. Corporation reputation has been defined by many authors in various ways. Fombrun (1996) stated that reputation is based on a set of collectively held beliefs about a company's ability and willingness to satisfy the interests of various stakeholders. Gray and Balmer (1998) stated that in today's competitive environment, the firms' ultimate survival depends upon building and maintaining a good corporate reputation. Corporate reputation conveys significantly important messages to several stakeholders which facilitates them in decision making regarding various transactions pertaining to corporations. Numbers of studies have identified the prospects of corporate reputation in the eyes of stakeholders. These stakeholders include investors who consider investing in any corporation owing to its reputation in the market, another important stakeholder in this context is the consumer who primarily takes into account, the corporate reputation in his purchase decision. For instance, Walsh et al. (2006) found a strongly significant association between corporate reputation and customer satisfaction in the context of Germany. Shapiro (1983) and Wilson (1985) and Lines (2003) declared customers as one of the main stakeholders that spread the corporate reputation in the market. Helm et al. (2010) also analyzed the relationship between corporate reputation and consumer satisfaction and declared corporate reputation as an antecedent of consumer satisfaction.

\section{Model Development and Hypotheses Formulation}

\section{Trustworthiness and Customer Satisfaction}

Thomas (2009) defines trust as "an expectancy of positive outcomes, outcomes that one can receive based on the expected action of another party". A key aspect that is reflected in this definition of trust is credibility. Credibility affects the long-term orientation of a customer by reducing the perception of risk associated with opportunistic behaviour by the firm. Specifically, trust reduces uncertainty in an environment where customers feel vulnerable because they know they can rely on the trusted organization (Aydin \& Ozer 2005). Trust is an important factor in affecting relationship commitment and customer satisfaction. If one party trusts another, such a party is willing to develop a positive behavioural intention toward the other party. Accordingly, when a customer trusts a business or brand, that customer is willing to form a positive buying intention towards the business. The relationship between customer trust and customer satisfaction is supported by reciprocal arguments. When service providers act in a way that builds customer trust, the perceived risk with the service provider is reduced, thus enabling the customer to make confident predictions about the service provider's future dealings. The development of trust is further considered an important result of investing in a dyadic and affective relationship between the parties in the relationship. Increased trust is cited as critical for relationship success between the customer and the business (Huang \& Chiu 2006). A customer will desire a relationship with a specific business if he finds the benefits received to exceed the effort in obtaining benefits. From this, it is evident that both parties in the relationship have certain costs or effort, but also expect benefits (Rootman 2006). The benefits that customers seek through the relationship are satisfaction, value and quality, while the business ultimately endeavours to create long-term loyalty and profitability (Wetsch 2005). We, therefore, expect a negative relationship between trustworthiness and customer satisfaction, as in the following hypothesis: 
$\mathrm{H}_{1}$ : Trustworthiness has no significant relationship with customer satisfaction in the Nigerian telecommunication industry.

\section{Corporate Social Responsibility and Customer Satisfaction}

The concept of CSR has emerged because of the growing significance of contributions to the wellbeing of society (Carroll, 1999). Even though CSR is a prevalent subject in management and marketing literature, the consensus definition of CSR is still unclear (Mackenzie \& Peters, 2014). CSR can be defined as an obligation of a firm via its operations and activities to be accountable to all of its stakeholders (Nicolau, 2008). However, Garay and Font (2012) defined CSR as the voluntary contribution of firms to environmental, economic, and social development. Moir (2001) defined CSR as "the continuing commitment by business to behave ethically and contribute to economic development while improving the quality of life of the workforce and their families as well as of the local community and society at large" (p. 18). Jamali (2008) stated that CSR is concerned with the commitment to contribute to sustainable development and the improvement of community conditions. Ismail (2009) stated that CSR could refer to any company actions toward all stakeholders, regardless of being ethical or responsible. The study of Jose, Rugimbana, and Gatfield (2012) also revealed that CSR impacts consumer behaviours, purchase intentions, and buying behaviours. CSR and customer satisfaction Garcia-Madariaga and Rodriguez-Rivera (2017) argued that CSR can raise levels of satisfaction. Ashraf, Ilyas, Imtiaz, and Tahir (2017) discovered that CSR influences the level of satisfaction positively and directly. Qamar, Masood, and Junaid (2016) concluded that CSR activities implemented by banks have a positive effect on customer satisfaction and retention. Perez and Rodríguez-del-Bosque (2015a) illustrated that CSR has a more positive effect on customer satisfaction than customer emotion and identification. This leads to the following competing hypothesis on the relationship between corporate social responsibility and customer satisfaction:

H2: Corporate social responsibility has no significant relationship with customer satisfaction in the telecommunication industry in Nigeria.

\section{Credibility and Customer Satisfaction}

Branding and brand credibility has been received substantial attention from market practitioners and researchers for many years and it is considered as one of the most significant upshots. Brand credibility develops with the brand experience when consumers utilize the product. It refers to the product positioning in the minds of the consumers to build customers choice (Bougoure and Bennett, 2016). Consumer-based brand credibility in the service context has not been playing its due role despite research advancement in this direction $(\mathrm{He}$ and $\mathrm{Li}$, 2011). Marketing discipline is urged a fundamental shift from the measurement of a construct to exploring its causal relationship in the area of service-based brand credibility (Spry et al., 2011). It is very important to retain the customers by the service organizations. In case of service failures, customers leave the company's service and move towards alternate services (Berger and Brock, 2018). The failure happens when expected services do not meet customers' demands. In fact, service failure is partially controllable and if it happens, the company should reestablish customer satisfaction to retain customers (Lee, 2018). Complaint handling has a significant positive impact to measure the short and long term performance of the service organization (Yilmaz and Varnali, 2016). Mismanaging in complaint handling is a threat for the organization that they might lose existing customers. Similarly, when customers get the 
recovery against failure from the service organizations, then they experience a sense of justice (Ladeira and Santini, 2018). In this connection, social media is being used as an important tool to address complaints and collect reviews of consumers about service (Istanbulluoglu, 2017). The other way around, failure is an opportunity to improve the services. In the complainthandling process, organizations always learn two things i.e. customer response factor and organizational learning factors. From the managerial point of view, the marketers can improve forecasting accuracy by using this customer's information that helps them to take better decision making (Horn et al., 2014).

H3: There is no significant relationship between credibility and customer satisfaction in the Nigerian telecommunication industry.

\section{Reliability and Customer Satisfaction}

Reliability refers to the ability of service organizations to perform the promised service dependably and accurately, and thus reflects the consistency and dependability of an organization's performance Rodriques, Bonar \& Sacchi (2011). Wilson et al. (2008) state that reliability means that the organization delivers on its promises about service delivery, service provision and problem resolution. Even though unreliable service providers are extremely frustrating for customers, a disturbing number of organizations still fail to keep their promises regarding service delivery. In many instances, the customer is ready to spend money if only the service provider will show up and conduct the transaction as promised, Bateson \& Hoffman (2011). Reliability is consistently the most important determinant of perceptions of service quality Wilson, Zeithaml, Bitner \& Gremler, (2008). Stiakakis and Georgiadis (2009) found reliability as a fundamental criterion of superior electronic service quality. Yang and Fang (2004) stated that reliability consists of accurate order of fulfilment, accurate record, accurate quote, accurate billing, and accurate calculation of commissions which keep the service promising to the customer. Thus, we hypothesized the following:

H4. Reliability had no significant relationship with customer satisfaction in the Nigerian telecommunication industry.

\section{THEORETICAL REVIEW}

\section{Corporate Reputation Framework}

Corporate Reputation is the endpoint in a chain. A chain that comes from the corporate image, with the corporate image coming from the corporate identity or brand; which will, in turn, come from the personality that the organization is trying to create. All of these elements are wrapped up in the corporate communications that the company is producing. 


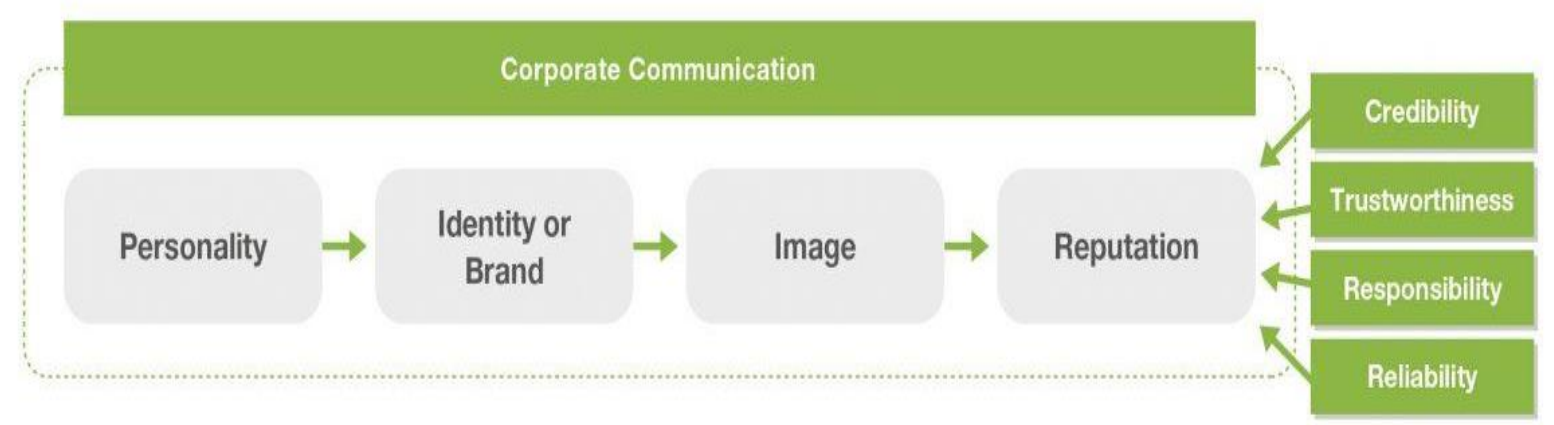

Source: http://www.studiowide.co.uk/blog/corporate-reputation

Corporate Reputation acts as a lynchpin for all of these concepts in the reputation framework, with lots of things feeding into it such as the image and reputation and what the organization does to enhance the reputation. The main benefits of having a solid reputation are trustworthiness and credibility. Corporate Reputation determines the levels of credibility, trustworthiness, responsibility and reliability that a stakeholder has with the organization. It's also worth noting that an organization may own a brand and may also try to create its image around that brand, but it is the stakeholder that owns and creates the reputation. In summary, it doesn't really matter what a company does, because what determines the organization's reputation is what the stakeholder's think of it; managing Corporate Reputation is, therefore, all about managing the stakeholder's perceptions.

\section{Reputation Risk Management Theory}

This theory justifies the fact that there is a strong relationship between corporate reputation, customer satisfaction, customer base, and business performance. The concept of corporate reputation is a collective phenomenon as it revolves around a given group's (stakeholders) ability to recognize and correctly interpret 'what a firm stands for' (Rose \& Thomsen, 2004). Reputation is formed on perceptions, that it is an aggregate perception of all stakeholders, and that it combines a firm's past actions, current state, and prospects (Walker, 2010; Dowling \& Morgan, 2012). Reputation risk management theory questions the explanatory power of previous theories such as institutional/legitimacy theory of impression management theory because they are perceived as excessively broad (Unerman, 2008).

Scholars have suggested taking into account, the complexity of external and internal corporate factors that might lead companies to report on their corporate reputation. Bebbington, Larrinaga \& Moneva, (2008) consider that corporate reputation reporting could be conceived as both an outcome of and part of reputation risk management processes. Friedman \& Miles (2001) suggest that a company's reputation lens "would make companies more aware of the need to manage a wide range of environmental, social and ethical risks and to show externally that they are doing so; this would increase the quantity and quality of corporate reputation. 


\section{Empirical Review}

A study by Agu, Maduagwu, and Ugwu, (2017) on the effect of corporate reputation on the performance of the selected commercial bank in Enugu State, Nigeria. The study aimed to investigate the effect of corporate reputation on the performance of the selected commercial banks in Enugu State, Nigeria. The study used a population size of 355, out of which a sample size of 188 was realized using Taro Yamane's formula at 5\% error to tolerance and $95 \%$ level of confidence. Instruments used for data collection were primary questionnaires and interviews. The total numbers of 188 copies of the questionnaire were distributed while 177 copies were returned and 11 copies were not returned. A survey research design was adopted for the study. Three hypotheses were tested using the Pearson product-moment correlation coefficient and a simple linear regression tool. The findings indicated that quality product significantly affects productivity in selected Commercial Bank. The study concluded that a corporate reputation is a tool used by firms to attract the best employees, raise capital effectively, gain and retain loyal customers. The study recommends that organizations should ensure that their products are of good quality that will serve as a competitive tool to win the market, retain the new customer and that will enhance productivity and increase profitability.

Abdullahi, Aminu, and Mustapha, (2014) carried out a study on the corporate reputation on performance of Banking Industries in Nigeria. The study examined the influence of corporate reputation on the performance of banking industries in Kano state. A survey with 384 qualified observations from financial institutions' customers in Kano was conducted. Partial Least Squares (PLS-SEM) was used as an alternative to covariance-based SEM, which provides the researcher with some flexibility in terms of model complexity and relationship specification. The model shows the corporate reputation that is a reflective construct that has a significant direct effect on performance. Findings are useful for policymakers, management of banking industries, and practitioners to enhance corporate reputation, implications for research and practice.

Lee and James, (2012) in another study titled revisiting corporate reputation and firm performance link. The study indicates a significant positive linkage between corporate reputation and performance, the results of the study have established the significant effect of corporate reputation on the performance firm. The study recommended that further interpretation of the findings for other countries should be made with caution.

While, Blajer-Golebiewska (2014), examined a similar study titled corporate reputation and economic performance; the evidence from Poland stated that relations between indicators of corporate reputation and economic performance in Poland are weak. There were just a few statistically significant correlations and most of them were weak. The reason for this is that despite a low level of interest in promoting corporate reputation (through engaging companies in CSR events), companies of better performance have more funds, and they are more conscious of the importance of this issue.

Li, Chen, and Ma (2016) examined corporate reputation and performance: A legitimacy perspective. Information was gathered from 191 enterprises in 16 provinces in China. In total, 300 enterprises were selected to participate in the study. Which the results suggest that corporate reputation has a significant positive relationship with enterprise growth. This means that brand image, social responsibility, innovation capability, and staff quality are all important to enterprise growth. Similar effects were found for innovation legitimacy on enterprise 
growth, indicating that legitimacy is an important theoretical perspective in understanding how businesses could develop in various important aspects.

\section{METHOD}

The survey research design method was employed in this study. The research instrument was a validated structures questionnaire. A five-point Likert scale was used to measure responses. The reliability of the questionnaire was estimated by assessing the internal consistency of the items representing each construct. Using Cronbach's alpha to establish reliability of each construct, total correlations were as follows: trustworthiness $=0.74$; corporate social responsibility $=0.81$ credibility $=0.79$; and reliability $=0.86$ and customer satisfaction $=0.84$. Favourably reliable scores were obtained from all items since all values were above 0.60 , which exceeded the common threshold value recommend by Malhotra (2004). Out of the 135 sets of questionnaires administered, 108 were returned and 8 were rejected due to incomplete information. Therefore, only 100 (74\%) were found usable. The hypotheses were tested using correlation and multiple regression analysis techniques.

\section{RESULTS}

Table 1: Correlation Matrix for Trustworthiness (TW), Corporate Social Responsibility (SR), Credibility (CD), Reliability (RB) and Customer Satisfaction (CS)

\begin{tabular}{|l|l|l|l|l|l|}
\hline & TW & SR & CD & RB & CS \\
\hline TW & 1 & & & & \\
\hline SR & $.68^{* *}$ & 1 & & & \\
\hline CD & $.71^{* *}$ & $64^{* *}$ & 1 & & \\
\hline RB & $.61^{* *}$ & $77^{* *}$ & $62^{* *}$ & 1 & \\
\hline CS & $.64^{* *}$ & $70^{* *}$ & $68^{* *}$ & $63^{* *}$ & 1 \\
\hline
\end{tabular}

Note: $\mathrm{N}=100$ and $* * \mathrm{p}<.01$

The above table examined the correlation among Trustworthiness (TW), Corporate Social Responsibility (SR), Credibility (CD), Reliability (RB) and Customer Satisfaction (CS) SR, $\mathrm{CD}, \mathrm{RB}$, and CS were positively and significantly correlated with TW $(\mathrm{r}=.68, \mathrm{p}<.01) ;(\mathrm{r}=71$, $\mathrm{p}<.01) ;(\mathrm{r}=.61, \mathrm{p}<.01) ;(\mathrm{r}-64, \mathrm{p}<.01)$. On the other hand CD, RB and CS were positively and significantly correlated with SR $(r=.64, \mathrm{p}<.01) ;(\mathrm{r}=77, \mathrm{p}<.01) ;(\mathrm{r}=.70, \mathrm{p}<.01)$. RB and CS were also positively correlated with $\mathrm{CD}(\mathrm{r}=.62, \mathrm{p}<.01) ;(\mathrm{r}=68, \mathrm{p}<.01)$ and with $\mathrm{CD}(\mathrm{r}=.62$, $\mathrm{p}<.01) ;(\mathrm{r}=68, \mathrm{p}<.01)$ and CS was positively correlated with $\mathrm{RB}(\mathrm{r}=63, \mathrm{p}<.01)$. 
Table 2: Summary of Multiple Regression Analysis of Trustworthiness (TW), Corporate Social Responsibility (SR), Credibility (CD), and Reliability (RB) on Customer Satisfaction (CS)

\begin{tabular}{|l|l|l|}
\hline S/N & Variables & Standard Beta \\
\hline 1 & TW & $0.251 * *$ \\
\hline 2 & SR & $0.283^{* *}$ \\
\hline 3 & CD & $0.198^{* *}$ \\
\hline 4 & RB & $0.219 * *$ \\
\hline 5 & CS & $0.226 * *$ \\
\hline 6 & R2 & 0.259 \\
\hline 7 & Adjusted R2 & 0.217 \\
\hline 8 & F value & 17.051 \\
\hline 9 & Sig & .000 \\
\hline 10 & Durbin Watson & 1.304 \\
\hline$* \mathrm{P}<0.01$ & \\
\hline
\end{tabular}

Regression analysis was conducted to access $\mathrm{H}_{1}, \mathrm{H}_{2}, \mathrm{H}_{3}$ and $\mathrm{H}_{4}$. As depicted in the regression table, the coefficient of $\mathrm{R}_{2}$ was 0.259 , indicating that four dimensions of independent variables explained $26 \%$ of the variance in customer satisfaction. In hypotheses $\mathrm{H}_{1}, \mathrm{H}_{2}, \mathrm{H}_{3}$ and $\mathrm{H}_{4}$ we investigated the influence of Trustworthiness (TW), Corporate Social Responsibility (SR), Credibility (CD), and Reliability (RB) on Customer Satisfaction (CS). It was revealed that TW $(\mathrm{B}=0.251, \mathrm{P}<.001) ; \mathrm{SR}(\mathrm{B}=0.283, \mathrm{P}<.001) ; \mathrm{CD}(\mathrm{B}=0.198, \mathrm{P}<.001)$ and $\mathrm{RB}(\mathrm{B}=0.219$, $\mathrm{P}<.001)$ were respectively significant and exhibited significant positive effects on customer satisfaction. Invariably $\mathrm{H}_{1}, \mathrm{H}_{2}, \mathrm{H}_{3}$ and $\mathrm{H}_{4}$ were supported. Hypothesis $\mathrm{H}_{1}, \mathrm{H}_{2}, \mathrm{H}_{3}$ and $\mathrm{H}_{4}$ examined the path from trustworthiness, corporate social responsibility, credibility, and reliability on customer satisfaction.

\section{DISCUSSION OF FINDINGS}

The purpose of the study was to determine the effect of corporate reputation on customer satisfaction in the Nigerian telecoms industry. The results of correlation analyses involving all dimensions of cooperation's reputation reported a positive correlation among the indicators of corporate reputation. Specifically, ethical value exhibited a relatively high level of coefficient value with cooperating social responsibility $(\mathrm{r}=.77, \mathrm{P}<.01)$. On the other hand, the result of the regression analysis shows that trustworthiness (TW) has a statistically positive effect on customer satisfaction $(\mathrm{B}=.251, \mathrm{P}<.01)$. This result provides support for $\mathrm{H} 1$. This is consistent with the views of Greeves (2010), Kim (2005) and Bennet (2001) which affirmed that trustworthiness as a dimension of corporate reputation is an antecedent of behavioural intention and an important aspect of customer satisfaction. The implication is that the benefits of satisfying mobile phone subscribers by providing trustworthiness are enhancing the corporate reputation that results in customer satisfaction.

Also, the result of regression analysis shows that corporate social responsibility exhibited a significant positive effect on customer satisfaction $(B=0.283, P=.001)$. Invariably, this result 
provided support for H2. This is in agreement with Sow (2011) and Onuoha (1999) findings that CSR focused businesses would proactively promote the public interest and restraint ultimate destructive activities. This suggests that a company's CRS can foster corporate reputation which may serve as a quality promise for customers. This may not be unconnected with why most mobile telecoms outfits embark on different CSR activities, towards improving stakeholder's welfare, value judgment and good reputation that supports customer satisfaction.

Similarly, the result of regression analysis recorded that credibility (CD) has a significantly positive effect on customer satisfaction ( $\mathrm{B}=0.198, \mathrm{P}<0.01$ ). These findings provide support for H3. This is a coefficient with Chaudhuri and Holbrook (2001) and Morgan and Hunt (1994) findings which highlighted that credibility leads to brand loyalty and commitment because credibility creates an exchange relationship that is highly valued. This implies that credibility is an important aspect among mobile telecom operators. Thus, the issue of credibility seems an important factor in building customer satisfaction.

In furtherance, the result of the regression analysis also reported that reliability (RB) exhibited a significant positive relationship with customer satisfaction $(B=0.219, p<0.001)$. Invariably, this finding provides support for $\mathrm{H} 4$. This is in consonance with findings that business must be conducted in a manner that gives the telecoms industry a positive reputation (Burton, 2007). The implication is that there seems to be consciousness among the telecoms regulatory agencies which relates to introducing reliability as an integral part of professional practice.

\section{CONCLUSION}

The major conclusion that emerged from the findings is that corporate reputation is a multifaceted construct whose dimensions have significant positive relationships with marketing performance outcome of customer satisfaction in the mobile telecommunications services industry. The study confirmed the overwhelming influence of corporate social responsibility as an indicator of corporate reputation on customer satisfaction. Thus, when companies integrate social and environmental responsibility into their brands, an impression of rational and emotional appeal is created that serves as promotional efforts and fosters customer satisfaction.

The potential importance of reliability as a means of eliciting customer satisfaction is revealed in this study. Thus, conducting a business in a manner that promotes high-reliability standards and a positive image foster a kind of reputation that will enhance customer satisfaction and marketing performance in the mobile telecommunication industry. Furthermore, it is also inferred that trustworthiness and credibility seem to play important roles in engendering positive behavioural intentions towards increasing the number of satisfied customers. In this regard, the benefits of providing good service quality will promote credibility and enhance corporate reputation and image which are important in building customer satisfaction in the competitive mobile telecoms sector. 


\section{Recommendations}

Operationally, this study develops and validates separate measures of corporate reputation. In the competitive context, managers should determine which dimensions of corporate reputation are appropriate for their target segment and develop their positioning strategy as appropriate.

Regulatory measures can be improved towards addressing challenges in telecoms service quality and business ethical conduct among mobile telecoms operators in Nigeria. This suggests that regulatory agencies should encourage the kind of healthy competition that will promote good quality service and ethical standards.

Customer awareness organizations should be encouraged to demand greater attention and CSR commitment from telecom operators. This will go beyond connecting customers to the brand to improvement in stakeholders' welfare.

Government should play a more active role in establishing regulations to protect customers, society and the environment. They should encourage final customers to become more responsive and sanction those who act in an unethical manner and establish guidelines designed to control green marketing claims.

\section{Suggestions for Further Studies}

The limitations in this study can be addressed in further research. Data used were collected from few sample objects in Enugu State, thus the findings may not be generalized to the large population of telecoms service consumers in Nigeria. Therefore, further research would need to involve a larger sample size by extending the research to other geographical areas in Nigeria. Further research may need to examine the potential of corporate reputation in other sectors apart from the telecommunications sector. This is because corporate reputation seems to have a strategy that cuts across all industries and consumers.

\section{REFERENCES}

Abbdullahi, H. G., Aminu, A., \& Mustapha, N. (2014). Corporate reputation on performance of Banking Industries in Nigeria: Using PLS-SEM tool of analysis. European Journal of Business and Management, 6(24), 71-79.

Adeosun, L.P.K., and Ganiyu, R.A. 2013. Corporate reputation as a strategic asset. International Journal of Business and Social Science 4(2): 220-225.

Agu, O. A., Maduagwu, N. E., \& Ugwu, J. (2017). Effect of corporate reputation on the performance of the selected commercial bank in Enugu State, Nigeria. International Journal of Management Excellent, 10(1),.

Alabar, T.T. (2012) 'Electronic Banking Services and Customer Satisfaction in the Nigerian Banking Industry', International Journal of Business and Management Tomorrow, Vol. 2 (3), pp 1-8.

Allen-Bach, M. (2000). Winning the war of the Mind through Reputation spinning. Marketing Communications Journal, Issue 3, Vol 2. Centre for Corporate Strategy Studies, University of Ghana, Legon. An International Journal, 19(4), 410-430. 
Anderson, E.W., Fornell, C. and Lehmann, D.R. (1994). "Customer Satisfaction, Market Share and Profitability: Findings from Sweden", Journal of Marketing, Vol. 58. Pp 5366.

Anderson, E.W; Sullivan, M.W. (1994). The antecedents and consequences of customer satisfaction for firms. Marketing Science, 12:125-43.

Ashraf, S., Ilyas, R., Imtiaz, M., \& Ahmad, S. (2018). Impact of Service Quality, Corporate Image and Perceived Value on Brand Loyalty with Presence and Absence of Customer Satisfaction: A Study of four Service Sectors of Pakistan. International Journal of Academic Research in Business and Social Sciences, 8(2): pp. 452-474.

Auger, P., Devinney, T. M., Dowling, G. R., Ecker, C., \& Lin, N. (2013). How much does a company's reputation matter in recruiting? MIT Sloan Management Review, 54: 79-88.

Aydin, S. \& Ozer, G. 2005. 'How switching costs affect subscriber loyalty in the Turkish mobile phone market: an exploratory study', Journal of Targeting, Measurement and Analysis for Marketing, 14(2): 141-155.

Bateson JEG, Hoffman KD (2011) Services Marketing International edition. (4th edn), Canada: South-Western Cengage Learning. pp. 277.

Bebbington, J., Larrinaga, C., \& Moneva, M. (2008). Corporate social reporting and reputation risk management. Accounting, Auditing \& Accountability Journal, 21(3), 337-361.

Bennett, R.; and Kottasz, R. (2000). Practitioners perceptions of corporate reputation: An empirical

Bergel, M. and Brock, C. (2018). The impact of switching costs on customer complaint behaviour and service recovery evaluation. Journal of Service Theory and Practice, 28(4), 458-483.

Blajer-Golebiewska, A. (2014). Corporate reputation and economic performance: The evidence from Poland. Economics and Sociology, 7(3), 194-207.

Bolton, R.N. (1998) - A dynamic model of the duration of the customer's relationship with a continuous service provider: the role of satisfaction", Marketing Science, Vol. 17 No. 1, pp. 45-65.

Bougoure, U.S. and Bennett, R.R. (2016). The impact of service failure on brand credibility. Journal of Retailing and Consumer Services, 31, 62-71.

Boulding, W., Kalra, A., Richard, S. \& Zeithaml, V. A. (2000). A dynamic process model of service quality: From expectations to managerial intentions. Journal of Marketing Research, 30(1), 7-27.

Carroll, A. B. (1999). Corporate social responsibility: Evolution of a definitional construct. Business \& Society, 38(3), 268-295.

Chun, R. (2005). Corporate reputation: meaning and measurement. International Journal of Management Reviews 7(2): 91 - 109.

Deephouse, D. L. (2000). Media reputation as a strategic resource: An integration of mass communication and resource-based theories. Journal of Management, 26(6), 10911112.

Doro, S., \& Eguruhin, D. (2000): Mapping the Reputational Landscape. Corporate Reputation Review, Ozerali, J. (2004): Strategic stakeholders Management: A Public Relations Approach. Hochdon Publications, Pretoria. Vol. 4, pp. 20 - 31.

Dowling, J., \& Morgan, J. (2012). Organizational legitimacy, social values and organizational behaviour. Pacific Sociological Review, (18). 122-136.

Fombrun, C.J. 1996. Reputation: realizing value from the corporate image. Harvard Business School Press. 
Friedman, A. L., \& Miles, S. (2001). Socially responsible investment and corporate social and corporate social and environmental reporting in the UK: An exploratory study. British Accounting Review, 33(4), 523-548.

Garay, L., \& Font, X. (2012). Doing good to do well? Corporate social responsibility reasons, practices and impacts in small and medium accommodation enterprises. International Journal of Hospitality Management, 31(2), 329-337.

Garcia-Madariaga, J., \& Rodriguez-Rivera, F. (2017). Corporate social responsibility, customer satisfaction, corporate reputation, and firms' market value: Evidence from the automobile industry. Spanish Journal of Marketing-ESIC, 21(1), 39-53. doi:10.1016/ j.sjme.2017.05.003

Gatti, L., Caruana, A., \& Snehota, I. (2012). The role of social responsibility, perceived quality and corporate reputation on purchase intention: Implications for brand management. Journal of Brand Management, 20: 65-76.

Gerpott, T. J. (1998)- Wettbewerbsstrategien im Telekommunikationsmarkt (3rd ed.). Stuttgart: Schaffer-Poeschel.

Gerpott, T., Rams, W., \& Schindler., A., (2001). Customer retention, loyalty and satisfaction in the German Mobile Cellular telecommunications market. Telecommunication Policy, 25(4), 249-269.

Grahame, R. D. (2016). Defining and measuring corporate reputations. European Management Review, 1-17.

Guo, L., Xiao, J. J., \& Tang, C. (2009). Understanding the psychological process underlying customer satisfaction and retention in a relational service. Journal of Business Research, 62 1152-1159.

He, H. and Li, Y. (2011). Key service drivers for high-tech service brand equity: the mediating role of overall service quality and perceived value. Journal of Marketing Management, 27(1), 77-99.

Heinberg, M., Ozkaya, H. E., \& Taube, M. (2018). Do corporate image and reputation drive brand equity in India and China? Similarities and differences. Journal of Business Review, 86, 259-268.

Heinberg, M., Ozkaya, H. E., \& Taube, M. (2018). Do corporate image and reputation drive brand equity in India and China? Similarities and differences. Journal of Business Review, 86, 259-268.

Helm, S., Eggert, A. and Garnefeld, I. (2010). Modelling the Impact of Corporate Reputation on Customer Satisfaction and Loyalty Using Partial Least Squares. Handbook of Partial Least Squares, Part 2, pp. 515-534.

Horn, C.F., Brem, A. and Ivens, B. (2014). Damaging brands through market research: Can customer involvement in prediction markets damage brands? Marketing Intelligence \& Planning, 32(2), 232-248.

Huang, H.H. \& Chiu, C.K.(2006). 'Exploring customer satisfaction, trust and destination loyalty in tourism', Journal of American Academy of Business, 10(1): 156-159.

Ismail, M. (2009). Corporate social responsibility and its role in community development: An international perspective. Journal of International Social Research, 2(9), 199-209.

Istanbulluoglu, D. (2017). Complaint handling on social media: The impact of multiple response times on consumer satisfaction. Computers in Human Behavior, 74, 72-82.

Jamali, D. (2008). A stakeholder approach to corporate social responsibility: A fresh perspective into theory and practice. Journal of Business Ethics, 82(1), 213-231. 
Johnson, M. D., \& Fornell, C. (2000). A framework for comparing customer satisfaction across individuals and product categories. Journal of Electronic Psychology, 12(2), 267-286.

Jose, S., Rugimbana, R., \& Gatfield, T. (2012). Consumer responses to CSR driven microfinance strategy of banks - an empirical investigation based on India. International Journal of Business and Management, 7(21), 1-14.

Kim, M.-K., Park, M.-C., \& Jeong, D.-H. (2005). The effects of customer satisfaction and switching barriers on customer loyalty in Korean mobile telecommunication services. Telecommunications Policy, 28(2), 145-159. doi:10.1016/j. telpol.2003.12.003

Krueger, T.M., Wrolstad, M.A., and Van Dalsem, S. 2010. Contemporaneous relationship between corporate reputation and return. Managerial Finance 36(6): 482 - 490.

Ladeira, W.J. and Santini, O. (2018). Strategic orientation for failure recovery and performance behaviour. Marketing Intelligence \&amp; Planning, 36(6), 646-660.

Lee, J., \& James, J. R. (2012). Revisiting corporate reputation and firm performance link. Benchmarking: An International Journal, 19(4/5), 649-664.

Lee, S.H. (2018). Guest preferences for service recovery procedures: a conjoint analysis. Journal of Hospitality and Tourism Insights, 1(3), 276-288.

Lewis, S. (2003). Reputation and corporate responsibility. Journal of Communication Management 7(4): 356-394.

Li, G. H., Chen, W. Z., \& Ma, X. G. (2016). Corporate reputation and performance: A legitimacy perspective. Entrepreneurial Business and Economic Review, 4(3), 181-192.

Lin, J. S. C. \& Wu, C. Y. (2011). The role of expected future use in relationship-based service retention. Managing service quality, 21(5), 535-551.

Mackenzie, M., \& Peters, M. (2014). Hospitality managers' perception of corporate social responsibility: An explorative study. Asia Pacific Journal of Tourism Research, 19(3), 257-272.

Manusamy, J., Chellia, S. and Mun, H.W. (2010). "Service Quality Delivery and Its Impact on Customer Satisfaction in the Banking Sector in Malaysia", International Journal of innovation, Management and Technology, Vol. 1 (4), pp398-404.

Moir, L. (2001). What do we mean by corporate social responsibility? Corporate Governance: The International Journal of Business in Society, 1(2), 16-22.

Morgan, R.M. \& Hunt, S.D. 1994. 'The commitment-trust theory of relationship marketing', Journal of Marketing, 58: 20-38.

Nicolau, J. L. (2008). Corporate social responsibility: Worth-creating activities. Annals of Tourism Research, 35(4), 990-1006.

Nimako, S. G. (2012) 'Linking Quality, Satisfaction and Behaviour Intentions in Ghana's Mobile Telecommunication Industry' European Journal of Business and Management, Vol 4 (7), pp 1-18.

Oliver, R. (1997). Satisfaction: a behavioural perspective on the consumer. New York, McGraw Hill.

Oliver, R.L. (2000). Response determinants in satisfaction judgments. Journal of Consumer Research, 14, 495-507.

Parasuraman, A., Zeithaml, V. A., \& Berry L. L. (1988). SERVQUAL: A multiple-Itemscale for measuring consumer perceptions of service quality. Journal of Retailing, 64(1), 12 40.

Parker, C. and Mathews, B.P., (2001). "Customer Satisfaction: contrasting academic and consumers' expectations” Marketing Intelligence and Planning, Vol. 19 (1). Pp38-44. 
Perez, A., \& Rodríguez-del-Bosque, I. (2015a). Corporate social responsibility and customer loyalty: Exploring the role of identification, satisfaction and type of company. Journal of Services Marketing, 29(1), 15-25. doi:10.1108/JSM-10-2013-0272

Podony, J. (1993) A status-based model of market competition. American Journal of Sociology, 98, 4, 829-872.

Qamar, M. A., Masood, S., \& Junaid, T. (2016). Impact of corporate social responsibility on customer satisfaction and retention: Evidence from the banking sector of Pakistan. International Journal of Financial Economics, 5(3), 33-45.

Rindova, V. P., Williamson, I. O., Petkova, A. P., \& Sever, J. M. (2005). Being good or being known: An empirical examination of the dimensions, antecedents, and consequences of organizational reputation. Academy of Management Journal, 48(6), 1033-1049.

Roberts M. (2009). Customer retention strategies implemented by fast food outlets in the Guateng, Western Cape and Kwazulu-Natal provinces of South Africa: A focus on something fishy, Nando's and steers. African Journal of Marketing Management, 1(2), 70-80.

Rootman, C. (2006). The influence of customer relationship management on the service quality of banks. Nelson Mandela Metropolitan University.

Rose, S. K., \& Thomsen, D. K. (2004). Logistics service performance: Estimating its influence on market share. Journal of Business Logistics, 24(1), 27-55.

Satendra, T. \& Singh, A. P. (2011). Impact of service quality, customer satisfaction and trust on customer loyalty: A study with special reference to Telecommunication Company in Madhya Pradesh (India). Zenith International Journal of Business Economics and Management Research, 1(2), 66-78.

Shamma, H.M. 2012. Toward a comprehensive understanding of corporate reputation: concept, measurement and implications. International Journal of Business and Management 7(16): 151-169.

Shanka, M.S. (2012) 'Bans Service Quality, Customer Satisfaction and Loyalty in Ethiopian Banking Sector, Journal of Business Administration and Management Research, Vol. 1. pp 1-9.

Shapiro, C. (1983). Premium for high-quality products as returns to reputations. Quarterly Journal of Economics, 98(4):659-679

Source: http://www.studiowide.co.uk/blog/corporate-reputation

Spry, A., Pappu, R. and Cornwell, B.T. (2011). Celebrity endorsement, brand credibility and brand equity. European Journal of Marketing, 45(6), 882-909.

Stiakakis, E., \&Georgiadis, C. K. (2009). E-service Quality: Comparing the Perceptions of Providers and Customers. Managing Service Quality: investigation, Corporate Communications: An International Journal, 5(4):224-234.

Taylor, S.A. and Baker, T.L. (1994) - "An assessment of the relationship between service quality and customer satisfaction in the formation of consumers' purchase intentions", Journal of Marketing, Vol. 58, Summer, pp. 163-78.

Thomas, J. (2009). "“Trust" in customer relationship: addressing the impediments in research', Proceedings of Asia-Pacific Conference on Advances in Consumer Research, 346-349.

Turel, O. \& Sorento, A. (2006). Satisfaction with mobile services in Canada: An empirical investigation. Telecommunication Policy, 30(6), 314-331.

Unerman, J. (2008). Strategic reputation risk management and corporate social responsibility reporting. Accounting, Auditing \& Accountability Journal, 21(3), 362-364. 
Vavra, T.G. (1997) - Improving Your Measurement of Customer Satisfaction: A Guide to Creating, Conducting, Analyzing, and Reporting Customer Satisfaction Measurement Programs, ASQ Quality Press.

Walker, H. (2010). Examining corporate reputation and commitment to (BSR) organizational performance relation, Evidence from Manufacturing Sector in Nigeria. European Journal of Business and Management, 5(10), 71-89.

Wang, Y., Lo, H. P., \& Yang, Y. (2004). An integrated framework for service quality, customer value, satisfaction: Evidence from China's telecommunication industry. Journal of Information Systems Frontiers, 6(40), 325-340.

Wetsch, L.R. (2005). 'Trust, satisfaction and loyalty in customer relationship management: an application of justice theory', Journal of Relationship Marketing, 4(3): 29.

Yilmaz, C. and Varnali, K. (2016). How do firms benefit from customer complaints? Journal of Business Research, 69(2), 944-955.

Zeithaml, V. A., (2000). "Service Quality and Economic Worth of Customers: What we know and what we need to learn, Journal of the Academy of Marketing Science, Vol. 28 (1) pp67-85. 